\section{IN CONCLUSION}

Faithful to the concept of a global environment, and aware of the crucial interactions between socio-economic factors and major environmental problems, the participants of the Almería International Symposium on Desertification and Migration are convinced that the challenge of desertification must be addressed in a comprehensive manner, taking also into account the complex issue of environmentally-related migrations.

The Symposium believes that, fundamental to the issue of desertification and migration, is the fact that many people wish to be able to have the freedom to stay at home, on their own land, in their own culture. This is particularly the case in order to provide the family with stability. The Symposium believes that the corollary of the recognized right of freedom of movement is the right to remain.
The Symposium recommends that the negotiation process of the Convention to Combat Desertification should give increased attention to the phenomenon of desertification-induced migration, at the local, regional, and global, levels.

Finally, the participants of the Almería Symposium note with pleasure that [the host-country] Spain - being itself affected by desertification and owing to its geographic location and cultural links with many affected countries in the world - is offering to contribute concretely to a more effective fight against desertification within the framework of the Convention.

[Communicated by Dr Arthur H. Westing, whose account of the Symposium was published on pages 85-6 of our preceding issue. - Ed.]

\title{
Gold Medal for International Corporate Environmental Achievement
}

$\mathrm{T}^{\mathrm{T}}$ he World Environment Center's Gold Medal for International Corporate Environmental Achievement (the 'WEC Gold Medal') was created to recognize publicly industry's environmental initiatives and contributions to global environmental quality. Acceptance of the WEC Gold Medal constitutes not only public acknowledgement of previous successes, but also an ongoing commitment on the part of the recipient to maintaining or improving environmental excellence. Recipients include: S.C. Johnson \& Son, Inc.; Xerox Corporation; The Procter \& Gamble Company; Rohm and Haas Company; IBM Corporation; The Dow Chemical Company; The British Petroleum Co., p.l.c.; E.I. duPont De Nemours \& Co.; Exxon Company; and 3M.

Criteria for nomination include: 1) establishment and globally uniform application of an overall publiclyannounced, proactive, corporate environmental policy, when dealing with all levels of management, government, non-governmental organizations, local agencies, and private citizens; 2) using science and technology to achieve maximum compatibility between environmental

* WEC also sponsors and organizes timely workshops, one of which is described on pages 187-8 of this issue, followed by a brief account of WEC's origin and objectives. - Ed. protection and rehabilitation on one hand and sound economic development on the other; 3) international leadership in the environmental arena, as evidenced by: (a) extending a sense of responsibility and commitment to larger societal issues such as national development and environmental goals; (b) participating actively in programmes and projects that are designed to maintain or enhance the global environment and contribute to sustainable development; and (c) conducting employee and public environmental education and awareness programmes.

Recipients are selected by an independent, international jury of environmental experts from industry, government, and academia. The Medal is presented at a formal dinner in Washington, DC, USA, attended by senior representatives of industry, government, international and national agencies, environmental organizations, the diplomatic corps, and the media *.

ANN VENARDOS
Manager of Corporate Programs
World Environment Center (WEC)
419 Park Avenue South, Suite 1800
New York
NY 10016, USA.

ANN VENARDOS World Environment Center (WEC) 419 Park Avenue South, Suite 1800 NY 10016, USA.

\section{Francis L. Dale: A Personal Reflection}

$\mathrm{T}$ The occasion on that warm September weekend was a meeting of the World Council For The Biosphere - a rather esoteric group of senior environmental scientists from a dozen countries who pioneered concern over foreseeable environmental problems until they were taken up by ad hoc or other appropriate bodies - and the site was a classic Swiss hotel in the mountain hamlet of Sonloup, high above the northeastern edge of Lake Geneva. It was hardly the place where one expected to run into a former major-league baseball team president, White House appointee*, and newspaper publisher.

But Frank Dale was there as Media Adviser, listening carefully, taking notes, and commanding much attention

*Inter alia as Campaign Manager of President Nixon at his second re-election. - Ed. when he spoke in his rich baritone voice. For Ambassador Dale was not at all your 'garden' variety of sports impresario, political figure, or leading journalist - despite being all three. He was, in fact, someone deeply committed to the cause of utilizing economic, political, and communication, resources to the fullest to enhance the cause and prospects of the global environment. Upon his recent death, that cause lost a very good friend.

Frank Dale was born in Urbane, Illinois, educated at Duke and the University of Virginia, and headed majorleague baseball in Cincinnati. He represented his country in Europe as a World War II USNR commanding officer and a peace-time ambassador, and always spent countless hours on airplanes. His last years were based on California and Montana (as newspaper publisher and foundation head, respectively), until he died of a heart attack while 